\title{
DISCRICIONARIEDADE ADMINISTRATIVA E SUA NOVA CONCEPÇÃO EM FACE DOS PRINCÍPIOS CONSTITUCIONAIS
}

William Cornetta

ISSUE DOI: $10.21207 / 1983.4225 .234$

\section{RESUMO}

Este estudo pretende analisar a discricionariedade administrativa em face das concepções do pós-positivismo como tambám analisar a discrcionariedade em face dos princípios constitucionais no que se refere ao dever constitucional de motivar e agir eficientemente. Será discutido também se no Estado Constitucional de Direito é possível falar em supremacia do interesse público sobre direitos fundamentais.

Palavras-Chave: Direito. Direito Administrativo. Direito Constitucional. Discricionariedade. Discricionariedade Administrativa. Princípios Constitucionais.

\section{INTRODUÇÃO}

O presente estudo tem por objeto analisar a discricionariedade administrativa em face das concepções do pós-positivismo, ou seja, trata- 
se de rever o conceito de discricionariedade superando os paradigmas difundidos no positivismo, que é o uso da lógica mecanicista através da subsunção.

Buscamos aqui utilizar da hermenêutica jurídica através da construção da teoria estruturante de Muller, que definiu que texto normativo e norma são figuras diferentes.

Além disso, entendemos que a norma é construída em bases lingüísticas, com motivação e fundamentação, derivada da compreensão histórica e fática do intérprete. A norma não está contida abstratamente no direito material; na verdade ela é fruto da produção na linguagem como forma de produção de uma solução a um problema jurídico.

Tendo isto em vista, a Discricionariedade administrativa será analisada em uma nova concepção em face dos princípios constitucionais, analisando a possibilidade de se conciliar a resposta discricionária com o dever constitucional de motivar e agir eficientemente, que entendemos por sua não possibilidade, uma vez que discricionariedade e direito excluemse mutuamente.

Será analisando ainda se no Estado Constitucional de Direito é possível falar em supremacia do interesse público sobre direitos fundamentais, situação que discordamos dada a natureza dos Direitos Fundamentais que se sobrepõe aos demais Direitos.

Como último item deste artigo, analisaremos de que forma se põe o paradigma Administração e Jurisdicionado no Estado Constitucional; entendo que estes passam a ter a mesma posição já que ambos têm direitos e deveres uns com os outros.

Como conclusão deste artigo, pretendemos realizar uma crítica ao positivismo, que permite e admite discricionariedades, e então demonstrar que Discricionariedade e Direito se excluem mutuamente.

\section{O PÓS POSITIVISMO COMO BASE DE ANÁLISE DA DISCRICIONARIEDADE ADMINISTRATIVA}

Antes de adentrarmos no tema central deste artigo, faz-se necessário definir alguns pressupostos para a sua correta interpretação.

Inicialmente, devemos observar a questão do fundamento e do conceito de verdade, ou seja, não mais se busca a "essência" das coisas, 
mas sim, pelas condições de acesso ao universo simbólico e significativo produzido pela linguagem ${ }^{1}$, conforme teoria de Gadamer.

Utiliza-se também de uma nova teoria sobre a norma jurídica baseada na distinção entre texto e norma conforme teoria estruturante de Friedrich Müller, mediante a superação do silogismo mecanicista como forma de solução das questões jurídicas, como também do afastamento da busca da vontade do legislador na interpretação dos textos normativos e, por fim, no conceito de construção da norma decorrente da junção via aplicativo com a união da linguagem e da historicidade (no que se refere à historicidade, usa-se como fundamento a teoria de Heidegger).

Pretende-se com isto superar os conceitos difundidos no positivismo, em que a aplicação era uma operação lógica mecanicista na qual o aplicador realizava a subsunção do fato à norma e daí obtinha o resultado para o caso concreto.

Com isto, estabelecemos como base que a norma decorre da interpretação jurídica do texto normativo construindo assim que a norma é a resposta ao caso concreto.

Esta norma é construída em bases linguísticas, com motivação e fundamentação, derivada da compreensão histórica e fática do intérprete. Além disso, a norma não está contida abstratamente no direito material; ela é produzida na linguagem com o intuito de solucionar um problema jurídico.

Cumpre destacar que a historicidade interpretativa passa a ser o elemento fundamental da compreensão de norma jurídica servindo como suporte significativo para a linguagem, uma vez que não mais se pode falar em separação entre o estudo do direito e a realidade.

Observe ainda que para Gadamer, existe a superação do esquema sujeito-objeto; para ele interpretar é antes de tudo compreender e, para compreender, deve existir uma pré-compreensão, construída de uma estrutura prévia de sentido, que é a pré-compreensão.

No pós-positivismo, as normas jurídicas são entendidas como estruturas compostas a partir do resultado da interpretação dos dados linguísticos e extralinguísticos, conforme teoria estruturante de Müller.

\footnotetext{
1 ABBOUD, Georges. Jurisdição Constitucional e direitos fundamentais. São Paulo : Editora Revista dos Tribunais, 2011. p. 55.
} 


\section{DISCRICIONARIEDADE ADMINISTRATIVA E SUA NOVA CONCEPÇÃO EM FACE DOS PRINCÍPIOS CONSTITUCIONAIS}

\subsection{Evolução histórica do conceito de discricionariedade}

A evolução da discricionariedade administrativa vem de longa data: as primeiras noções do conceito remontam à Idade Média.

O Regime de governo típico da Idade Moderna compõe-se dos seguintes elementos: capitalismo comercial, política mercantilista, sistema colonial, sociedade estamental, Estado absolutista, intolerância religiosa e laicizarão cultural.

O absolutismo, com seu soberano autocrático, caracteriza esse conjunto e até mesmo o simboliza. Como observa Georges Abboud, o "Estado Absolutista pode ser definido monopólio da força sobre os três planos: jurídico, político e sociológico" 2 .

Ainda segundo o mesmo autor ${ }^{3}$, o Rei no Estado Absolutista possui a concentração dos poderes em suas mãos, isto é, "governa com a espada e com a lei”, que é representado pelo Gobernaculum e Iurisdicto.

Pelo Governaculum, o Rei relacionava-se com outros Estados e tratava internamente dos chamados assuntos de Estado. Este poder por sua natureza era discricionário, extra legem, ou seja, não podia ser exercido com base nas leis estabelecidas. Tratava-se de um poder arbitrário, já que o Rei não prestava contas a ninguém de sua execução ${ }^{4}$.

A discricionariedade era equiparada aos chamados "atos de império", oposta aos "atos de gestão".

Em oposição ao Governaculum, havia o Iurisdictio que consistia no dever de administrar a justiça, ou seja, ao exercer esse poder, o Rei estava limitado ao direito e deveria se pronunciar segundun legem ${ }^{5}$.

\footnotetext{
${ }^{2}$ ABBOUD, Georges. Discricionariedade: alcance da atuação administrativa e judicial no Estado Constitucional. Tese de Doutorado em Direito. Pointifícia Universidade Católica de São Paulo, 2013. p. 97.

${ }^{3}$ Ibidem.

${ }^{4}$ Idem. p. $97-98$.

${ }^{5}$ ABBOUD, Georges. Discricionariedade: alcance da atuação administrativa e judicial no Estado Constitucional. Tese de Doutorado em Direito. Pointifícia Universidade Católica de São Paulo, 2013. p. 97. p. 98.
} 
Então historicamente, duas principais correntes são desenvolvidas dentro da tradição administrativa. Uma corrente rígida e inflexível ao tratar a discricionariedade como limite à possibilidade de revisão dos atos administrativos pelo Judiciário. Nesta teoria, o ato administrativo qualificado como discricionário possui o traço da imunidade em relação à análise pelo judiciário ${ }^{6}$.

Na evolução histórica da discricionariedade, tal imunidade do ato administrativo discricionário tende a desaparecer, pois no Estado de Direito não se admitem poderes ilimitados.

O Brasil em sua construção da teoria jurídica administrativa, infelizmente, está bastante distante da evolução ocorrida em outros países. Nossos doutrinadores ainda defendem fielmente a discricionariedade administrativa demonstrando nosso atraso em relação às teorias adotadas em diversos países.

\subsection{Modalidades de discricionariedade}

Abboud faz um interessante levantamento das diferentes modalidades de discricionariedade e afirma também que ela é comumente apresentada com uma área que a Administração Pública decide ou determina algo de forma livre e desvinculada, figurando como uma atuação extra legem da administração perante uma multiplicidade de escolhas que o sistema normativo oferece ${ }^{7}$.

O mesmo autor observa ainda que a Discricionariedade compreende: o poder discricionário, atividade e ato discricionário, que são três momentos distintos, mas intrinsecamente ligados ${ }^{8}$.

\footnotetext{
${ }^{6}$ FERNÁNDEZ, Tomás Ramón. Discrecionalidad, Arbitrariedad y Control Jurisdiccional. Lima: Palestra Editores, 2006. p. 92.

${ }^{7}$ ABBOUD, Georges. Discricionariedade: alcance da atuação administrativa e judicial no Estado Constitucional. Tese de Doutorado em Direito. Pointifícia Universidade Católica de São Paulo, 2013. p. 132.

8 Ibidem.
} 
Com base na tese de Abboud $^{9}$, cada uma das teorias abaixo aponta um aspecto dominante da discricionariedade e junto delas trazemos também a crítica ao modelo adotado com base na teoria pós -positivista.

\subsubsection{Discricionariedade interpretativa}

A discricionariedade interpretativa, segundo Abboud, é aquela que se opõe à atuação vinculada da Administração ${ }^{10}$. O mesmo autor ${ }^{11}$ traz $^{2}$ o comentário de Castanheira Neves, na obra, "O problema da discricionariedade $^{12}$ ", que denota que a essência da discricionariedade reside na liberdade em relação à vinculação jurídica.

Desta forma, podemos entender a Discricionariedade interpretativa como contraposto ao ato vinculado. Ato vinculado, segundo Hely Lopes Meirelles ${ }^{13}$, é aquele que a lei estabelece os requisitos e condições de sua realização, deixando para o órgão nenhuma liberdade de decisão.

Observa ainda Abboud ${ }^{14}$ que principal marca do Ato vinculado é que a decisão proferida decorre do esquema e processo lógico-subsuntivo da aplicação da lei, isto é, trata-se da lógica mecanicista da subsunção do fato a lei.

Com isto, constrói-se o conceito do ato vinculado como aquele que encontra todos os seus requisitos na lei, ou seja, decorre direta e imediatamente da lei. Assim, a teoria administrativista construiu o conceito de discricionariedade como uma área em que o administrador teria margem para interpretar a legislação.

\footnotetext{
${ }^{9}$ ABBOUD, Georges. Discricionariedade: alcance da atuação administrativa e judicial no Estado Constitucional. Tese de Doutorado em Direito. Pointifícia Universidade Católica de São Paulo, 2013. p. 97.

${ }^{10}$ Idem. p. 134.

${ }^{11}$ Ibidem.

${ }^{12}$ CASTANHEIRA NEVES, Antonio. O problema da discrionariedade. In: Digesta: escritos acerca do Direito, do pensamento jurídico, de sua metodologia. Coimra Editora, 1996, v.1. p. 532-534.

${ }^{13}$ MEIRELLES, Hely Lopes. Direito Administrativo Brasileiro. 29a ed. Atualizado por Eurico de Andrade Azevedo et alii. São Paulo: Editora Malheiros, 2004. p. 116.

${ }^{14}$ ABBOUD, Georges. Discricionariedade: alcance da atuação administrativa e judicial no Estado Constitucional. p. 135.
} 
Assim, a Decisão discricionária, apesar de fundar-se na lei, não encontra nela seu critério de decisão, conforme observa Seabra Fagundes ${ }^{15}$. Ainda na linha do mesmo autor, nas hipóteses em que a lei deixa a autoridade administrativa livre para apreciar o motivo ou o objeto do ato, ou de ambos, ocorre a discricionariedade. Seabra ainda observa que o Motivo é a ocasião de praticar o ato, ou seja, a oportunidade; já a utilidade refere-se à conveniência, e por fim, o conteúdo trata-se do poder praticar o ato com objetivo variável ${ }^{16}$.

Abboud faz uma profícua crítica à discricionariedade interpretativa, pois esta constrói seu conceito com base na subsunção do fato à norma, de maneira que quanto menor a vinculação, maior seria o campo de interpretação da administração, isto é, maior margem discricionária ${ }^{17}$. Segundo o autor, trata-se de uma visão defasada sobre a hermenêutica jurídica e aplicação do direito ${ }^{18}$.

Nas palavras de Andreas J. Krell, "a qualificação de um ato administrativo como 'plenamente vinculado'- ainda comum na doutrina e na jurisprudência no Brasil - parece remontar aos equívocos da Escola de Exegese, que pregava que normas legais "serviriam de prontuários repletos e não lacunosos para dar solução aos casos concretos, cabendo ao aplicador um papel subalterno de automaticamente aplicar os comandos prévios e exteriores e sua vontade" ${ }^{19}$.

\subsubsection{Discricionariedade optativa}

Outra modalidade de discricionariedade é a interpretativa, pois representa a possibilidade de se realizar uma escolha dentre uma multiplicidade de opções possíveis.

${ }^{15}$ SEABRA FAGUNDES, Miguel. O controle dos atos administrativos pelo Poder Judiciário. 8. ${ }^{\mathrm{a}}$ ed. autal. por Gustavo Binenbojm. Rio de Janeiro : Foresen, 2010, p. 91-92.

${ }^{16}$ Ibidem.

${ }^{17}$ ABBOUD, Georges. Discricionariedade: alcance da atuação administrativa e judicial no Estado Constitucional. p. 137.

${ }^{18}$ Ibidem.

${ }^{19}$ KRELL, Andreas J. Discricionariedade Administrativa e conceitos legais indeterminados: limites do controle judicial no âmbioi dos interesses difusos. 2. ed. rev., atual. e ampl. - Porto Alegre : Livraria do Advogado Editora, 2013. p. 23. 
Parcela da doutrina entende que a eleição entre várias alternativas válidas é a essência do conceito de discricionariedade (vinculação positiva), mas também como limite (vinculação negativa), pois o ato só pode ser desqualificado juridicamente se a eleição contida nele colidir com os princípios gerais de direito ${ }^{20}$.

Abboud traz o comentário de Constantino Mortati: "neste contexto, julgamento de oportunidade do ato discricionário caracteriza-se em um momento pré jurídico, um momento que é meramente econômico, em que precede a escolha, ou que consiste em julgamento que se refere aos interesses insertos no ato quando, não foram pressupostos elementos teleológicos do ato" ${ }^{21}$.

Abboud também observa que discricionariedade optativa é um dos principiais subterfúgios para negar o exame do mérito, no que se refere à legalidade e a constitucionalidade do ato administrativo pelo judiciário ${ }^{22}$.

Assevera ainda Abboud que: "não se pode negar a possibilidade da lei ser interpretada de diversas formas, seja para a decisão judicial ou ato administrativo. De fato, a lei não pode ser confundida com norma e a multiplicidade de interpretação só ocorre no plano abstrato" ${ }^{23}$.

Destaque-se ainda que a discricionariedade optativa é um conceito que segue a doutrina relativista, ou seja, permitem-se várias soluções, mesmo que elas sejam conflitantes.

Por fim, adverte Abboud $^{24}$ que admitir a discricionariedade em um Estado Constitucional está negando ao direito a capacidade de solucionar os problemas jurídicos bem como a busca de resposta correta conforme a constituição ao caso conforme teoria de Lenio Luiz Streck ${ }^{25}$.

\subsubsection{Discricionariedade performática}

\footnotetext{
${ }^{20}$ ABBOUD, Georges. Discricionariedade: alcance da atuação administrativa e judicial no Estado Constitucional. p. 140.

${ }^{21}$ Idem. p. 141.

${ }^{22}$ Idem. p. 144.

${ }^{23}$ Idem. p. 145.

${ }^{24}$ Ibidem.

${ }^{25}$ STRECK, Lenio Luiz. Verdade e Consenso. Constituição, Hermenêutica e Teorias Discursivas da Possibilidade à necessidade de respostas corretas em Direito. 4.a Ed. revista, Porto Alegre : Livraria do Advogado, 2013, p. 334-335
} 
Nas palavras de Abboud: "Discricionariedade performática é a dimensão da discricionariedade que se justifica por si só. Vale dizer, são os atos administrativos que criam sua autoblindagem na medida em que afirmar estarem pautados ou no interesse público ou no critério de conveniência e oportunidade" ${ }^{26}$.

Abboud $^{27}$ também traz os comentários de John L. Austin ${ }^{28}$, que define que os termos performáticos englobam as expressões lingüísticas que seriam freqüentemente vazias de sentido nelas próprias ("um sem sentido"). Os enunciados performáticos não descrevem ou registram nada, eles não são nem verdadeiros nem falsos. Essa é a principal característica dos enunciados performáticos: eles são indiscutíveis, não provam nada e não pode ser refutados, já que não podem ser considerados verdadeiros ou falsos.

Entre os termos performáticos, podemos incluir o "interesse público" e a "conveniência e oportunidade", os quais, seguindo a teoria de Austin, apresentam uma vagueza semântica.

Neste sentido, Abboud ${ }^{29}$ ainda destaca que Judiciário nega-se a adentrar no exame do mérito do ato administrativo no critério de "interesse público" e "conveniência e oportunidade", desta forma o mérito deixa de ser efetivamente avaliado e os termos performáticos são utilizados como subterfúgio.

Como crítica a esta modalidade, deve-se observar que a Constituição em seu art. 37 define que os atos devem pautar-se pela legalidade, moralidade, publicidade, impessoalidade e eficiência. Logo, observa Abboud $^{30}$ que os critérios de conveniência e oportunidade devem passar por uma depuração hermenêutica para necessariamente atender os padrões impostos pelo mencionado artigo constitucional.

\footnotetext{
${ }^{26}$ ABBOUD, Georges. Discricionariedade: alcance da atuação administrativa e judicial no Estado Constitucional. p. 146.

${ }^{27}$ Idem. p. 146-149.

${ }^{28}$ AUSTIN, Jonh L. How to do things with words. 2. Ed, Cambridge: Harvard University Press, 1975. p. 4 et seq.

${ }^{29}$ ABBOUD, Georges. Discricionariedade: alcance da atuação administrativa e judicial no Estado Constitucional. p. 157-158.

${ }^{30}$ Ibidem.
} 


\subsubsection{Discricionariedade volitiva}

Outra modalidade de discricionariedade é a volitiva, que significa a concretização da vontade da lei ou do administrador.

Bandeira de Mello denota que é a espécie de atuação intelectiva ou volitiva, proporcionada pelo ordenamento à Administração ${ }^{31}$.

Abboud $^{32}$ traz à doutrina de Edimur Faria., que define o poder discricionário como a arte de escolher o melhor, de apreciar e avaliar todas as escolhas, tendo em vista a sua finalidade, sendo a finalidade coerente e compatível com o fim coerente com a lei.

Entendemos que todos os atos devem ser mais ou menos vinculados, mas não podemos falar em discricionariedade no Estado Democrático de Direito, ainda mais quando suportados pela teoria de hermenêutica jurídica. Poder discricionário, como ressalta $\mathrm{Abboud}^{33}$, não implica a liberdade plena para o agente público adote a postura segundo sua livre escolha.

Ricardo Marcondes Martins ${ }^{34}$ entende a discricionariedade como admissão de multiplicidade de respostas e identifica um fundamento constitucional do pluralismo (preâmbulo e Art. 1, V da CF) como princípio estruturante do ordenamento brasileiro.

Abboud $^{35}$ em contraposição acima, afirmar que não se pode subverter o pluralismo para que legitime a Administração/judiciário para escolher a solução que quiserem. No estado Constitucional, tanto a Administração quanto o Judiciário devem proferir a melhor solução possível do ponto de vista jurídico.

Nesta linha, podemos afirmar que questões jurídicas ou administrativas não podem ficar à mercê da vontade de ninguém. Concretização de preceitos constitucionais (Art. $37 \mathrm{CF}$ ) não pode ficar sujeita à vontade de nenhum administrador.

\footnotetext{
${ }^{31}$ BANDEIRA DE MELO, Celso Antonio. Discricionariedade e controle jurisdicional. 2.a Ed. 11.a tir. São Paulo : Malheiros Editores, 2012. p. 27.

${ }^{32}$ ABBOUD, Georges. Discricionariedade: alcance da atuação administrativa e judicial no Estado Constitucional. p. 160.

${ }^{33}$ Ibidem.

${ }^{34}$ MARTINS, Ricardo Marcondes. Efeitos dos vícios do ato administrativo. São Paulo: Malheiros, 2008, p 183.

${ }^{35}$ ABBOUD, Georges. Discricionariedade: alcance da atuação administrativa e judicial no Estado Constitucional. p. 162-163.
} 


\subsubsection{DISCRICIONARIEDADE TÉCNICA}

Segundo Antonio Francisco de Sousa ${ }^{36}$, o termo discricionariedade técnica foi utilizado pela primeira vez em 1864 por Berntzik, um dos autores da Escola de Viena.

$\mathrm{O}$ mencionado autor ${ }^{37}$ ainda assevera que Berntzik pretendia sob o conceito de discricionariedade técnica englobar todo aquele tipo de decisões que, não sendo discricionárias, deveriam, contudo ser, pela sua alta complexidade técnica.

Assim, a discricionariedade técnica é a atribuição à Administração, pela norma jurídica, de poder atuar com fundamento em critérios fornecidos por saberes especializados - derivados de ciências puras ou apli$\operatorname{cadas}^{38}$.

Abboud $^{39}$ observa que configura um choque entre Discricionariedade Técnica e Discricionariedade Optativa, isto é, a primeira busca conhecimento técnicos (ciências aplicadas) e a segunda, conveniência e oportunidade.

O mencionado autor ${ }^{40}$ ainda traz os comentários de Julio Rodolfo Comandira, Héctor Jorge Escola e Julio Pablo Comadira ${ }^{41}$, que entendem que a inexistência de discricionariedade técnica, pois segundo eles a atuação administrativa com fundamento em informações científicas ou técnicas é, em seu conteúdo, vinculada e não discricionária, ou seja, somente nos casos em que as conclusões científicas ou técnicas são unívocas e excludentes, livres de controvérsia.

Ainda segundo os autores acima ${ }^{42}$, nos casos de mais de uma solução técnicas possíveis, a Administração poderia escolher discricionariamente um critério não técnico para a eleição da solução. Uma chamada discricionariedade subseqüente à verificação de dados técnicos.

\footnotetext{
${ }^{36}$ SOUSA, Antônio Francisco de. Conceitos Indeterminados. Coimbra : Livraria Almedina, 1994, p. 105-106.

${ }^{37}$ Ibidem.

${ }^{38}$ ABBOUD, Georges. Discricionariedade: alcance da atuação administrativa e judicial no Estado Constitucional. p. 165-166.

${ }^{39}$ Ibidem.

${ }^{40}$ Ibidem.

${ }^{41}$ COMANDIRA, Julio Rodolfo; ESCOLA, Héctor Jorge e COMANDIRA, Julio Pablo.
} Custo de Derecho administrativo. Buenos Aires: Abeledo-Perrot, p 115-116.

${ }^{42}$ Ibidem. 
Abboud $^{43}$ traz a crítica a Miguel S. Marienhoff ${ }^{44}$ sobre discricionariedade técnicas que funda sua posição em três pontos principais: 1. Regra técnica deriva de critérios científicos não podendo ser relacionada com a discricionariedade; 2 . Em regra, a questão técnica é obtida a partir de um único critério científico; 3. Em regra, para a questão técnica o elemento interesse público é totalmente irrelevante

Não pode a administração ignorar a informação técnica e agir de forma discricionária; trata-se de agir necessariamente de forma vinculada ao material mais seguro.

Neste sentido, Maria Sylvia di Pietro ${ }^{45}$, observa que no caso da discricionariedade técnica, não há discricionariedade propriamente dita, pois não há opções a serem feitas por critérios de oportunidade e conveniência, existe uma única solução a ser adotada com critérios fornecidos pela ciência.

Não existe discricionariedade técnica; neste caso o ato deve ser vinculado e não discricionário.

Não apenas a Administração como o próprio judiciário, conforme destaca Abboud ${ }^{46}$, em determinadas oportunidades, deve utilizar critérios decorrentes de prova pericial (art. 420 e segs. do CPC). Ambos não podem desconsiderar as informações técnicas no momento da decisão, ou seja, questão técnica não pode ser afastada com base em critérios de conveniência ou oportunidade.

A questão técnica não existe por si só, ela passa integrar o mérito do ato administrativo ou da decisão judicial. Por isto, não há como se falar em blindagem do ato administrativo, pois funda-se em questões técnicas, uma vez que a técnica faz parte do mundo jurídico e do controle de razoabilidade do ato administrativo.

\footnotetext{
${ }^{43}$ ABBOUD, Georges. Discricionariedade: alcance da atuação administrativa e judicial no Estado Constitucional. p. 166.

${ }^{44}$ MARIENHOFF, Miguel S. Tratado de Derecho Administrativo, t. II, 5. a ed., Buenos Aires: Abeledo Perrot, 2011, n. 454. p. 345.

${ }^{45}$ PIETRO, Maria Sylvia Zanella di. Discricionariedade Técnica e Discricionariedade Administrativa. Revista Eletrônica de Direito Administrativo Econômico (REDAE), Salvador, Instituto Brasileiro de Direito Público, n.o 09, fevereiro/março/abril, 2007. Disponível na internet: http://www.direitodoestado.com.br/redae.asp acesso em 28 de setembro de 2013. p. 12.

${ }^{46}$ ABBOUD, Georges. Discricionariedade: alcance da atuação administrativa e judicial no Estado Constitucional. p. 168-169.
} 
Alta complexidade não é argumento que justifique validamente que os juízes elidam o controle da atividade administrativa como impõelhes a Constituição, já que o Judiciário pode usar da realização de perícia ${ }^{47}$.

\subsection{Elemento comum a toda discricionariedade alforria jurídico-constitucional}

Todas as teorias da discricionariedade acima tratam de uma alforria jurídico-constitucional, ou seja, onde existe discricionariedade ocorre um não-domínio do direito.

Marienhoff $\mathrm{f}^{48}$ situa a discricionariedade dentro do direito, contudo, fora dos parâmetros legais. Os critérios discricionários não estão contidos nos parâmetros legislativos. A discricionariedade é determinada por dados provenientes da política.

Elemento comum para discricionariedade, conforme observa Abboud $^{49}$, é a possibilidade de agir sem amarras jurídicas; a seu modo, a discricionariedade seria a sucessora do Gobernaculum.

Observa ainda o mesmo autor ${ }^{50}$ que não pode o Estado Constitucional tolerar a atuação do Poder Público que não tenha amparo direto no texto da constituição como também na legalidade vigente.

\subsection{Conceito e crítica de discricionário na doutrina administrativista}

Nas palavras de Celso Bandeira de Melo, o "chamado Poder Discricionário só pode existir como um poder "intra" legal e estritamente dependente da lei, ou seja, estritamente subordinado à lei. Por isto, o "poder"

\footnotetext{
${ }^{47}$ Ibidem.

${ }^{48}$ MARIENHOFF, Miguel S. Tratado de Derecho Administrativo. p. 331-332.

${ }^{49}$ ABBOUD, Georges. Discricionariedade: alcance da atuação administrativa e judicial no Estado Constitucional. p. 172-173.

${ }^{50}$ Ibidem.
} 
Discricionário jamais poderá resultar da ausência da lei que dispusesse sobre dado assunto " 51 .

Maria Sylvia di Pietro denota que "a fonte da discricionariedade administrativa é a própria lei; aquela só existe nos espaços deixados por esta. Nesses espaços, a atuação livre da Administração é previamente legitimada pelo legislador" ${ }^{52}$.

Com vênia aos dois autores mencionados, a doutrina administrativista brasileira adota, com grande ênfase, a discricionariedade administrativa, contudo esta posição é bastante equivocada frente à aplicação do direito na hermenêutica jurídica.

Neste sentido, cumpre observar o conceito de discricionariedade administrativa trazido por estes dois autores e uma crítica a eles.

Para Celso Antônio Bandeira de Melo: "Discricionariedade, portanto, é a margem de liberdade que remanesça ao administrador para eleger, segundo critérios consistentes de razoabilidade, um, dentre pelo menos dois comportamentos cabíveis, perante cada caso concreto, a fim de cumprir o dever de adotar a solução mais adequada à satisfação da finalidade legal, quando, por força da fluidez das expressões da lei ou da liberdade conferida no mandamento, dela não se possa extrair objetivamente, uma solução unívoca para a situação vertente". ${ }^{53}$

Podemos então destacar no conceito acima os seguintes pontos de atenção:

1.) Margem de liberdade;

2.) Eleição de pelo menos dois comportamentos;

3.) Critérios de razoabilidade, $\mathrm{e}$

4.) Finalidade mais adequada.

Conforme já analisado nas modalidades de discricionariedade acima, podemos perceber que o conceito apresentando por Bandeira de Mello relaciona-se com algumas delas.

Por sua vez, Maria Sylvia Zanella di Pietro entende que "Em alguns casos, o poder da Administração é discricionário, porque a adoção de

\footnotetext{
${ }^{51}$ MELO, Celso Antonio Bandeira de. Discricionariedade e controle jurisdicional. 2.a Ed. 11.a tir. São Paulo : Malheiros Editores, 2012. p. 13.

${ }^{52}$ PIETRO, Maria Sylvia Zanella Di. Direito Administrativo. 24.a Ed - São Paulo: Atlas, 2011. p 215.

${ }^{53}$ MELO, Celso Antonio Bandeira de. Discricionariedade e controle jurisdicional. p. 48.
} 
uma ou outra solução é feita segundo critérios de oportunidade, conveniência, justiça, equidade, próprios da autoridade, porque não definidos pelo legislador. Mesmo aí, entretanto, o poder de ação administrativa, embora discricionário, não é totalmente livre, porque, sob alguns aspectos, em especial a competência, a forma e a finalidade, a lei impõe limitações. Daí por que se diz que a discricionariedade implica em liberdade de atuação dentro dos limites traçados pela lei, se a Administração ultrapassa esses limites, a sua decisão passa a ser arbitrária, ou seja, contrária à lei" ${ }^{54}$.

Na mesma linha do conceito anterior, podemos perceber os seguintes pontos na construção de Maria Sylvia di Pietro:

1.) Critérios de oportunidade, justiça, conveniência, e

2.) Forma e finalidade.

Assim, podemos notar que tais teorias não estão adequadas a todo o trabalho doutrinário construído no presente artigo; os elementos trazidos por tais autores para construir sua teoria fundam-se na discricionariedade, relativismo, vontade do legislador e termos performáticos.

Não podemos, assim, coadunar com tais posições conforme será demonstrado ao longo do presente estudo.

\subsection{Princípios constitucionais relacionados à administração pública}

O Artigo 37 da Constituição Federal explicita os princípios de legalidade, impessoalidade, moralidade, publicidade e eficiência que devem ser observados pela Administração Pública em sua atuação.

CF Art. 37. A administração pública direta e indireta de qualquer dos Poderes da União, dos Estados, do Distrito Federal e dos Municípios obedecerá aos princípios de legalidade, impessoalidade, moralidade, publicidade e eficiência e, também, ao seguinte.

Nas palavras de José Afonso da Silva: "a administração pública é informada por diversos princípios gerais, de um lado, a orientar a ação

${ }^{54}$ DI PIETRO, Maria Sylvia Zanella. Direito Administrativo. 24.a Ed - São Paulo: Atlas, 2011.Cit., p 214. 
do administrador na prática dos atos administrativos e, de outro lado, a garantir a boa administração, que se consubstancia na correta gestão dos negócios públicos e no manejo dos recursos públicos (dinheiro, bens e serviços) no interesse coletivo, com o que também se assegura aos administrados o seu direito a práticas administrativas honestas e probas" 55 .

Conforme Abboud, "Princípio da legalidade, no que se refere à atuação do Poder Público, deve ser compreendido de duas formas. Em um primeiro momento, deve ficar estabelecido que a Administração Pública, ainda que com menor margem de manobra que o Judiciário, também interpreta a legislação vigente para executar sua atividade. $\mathrm{O}$ segundo aspecto do princípio da legalidade a ser desmistificado diz respeito à colocação da Constituição como fundamento direto do agir administrativo" 56.

E ainda segundo o mesmo autor "Sujeito administrativo tem menor margem de manobra interpretativa em relação ao magistrado que possui atividade jurisdicional" ${ }^{57}$, ou seja, apesar de ter uma margem de manobra menor, a Administração faz a interpretação legislativa para poder exercer suas funções. "A norma é produto do intérprete, nunca sua descoberta, de modo que a Administração Pública para poder exercer sua atividade nos parâmetros da legislação aplicável deverá obrigatoriamente interpretar essa legislação. A Administração não realiza sua atividade de forma meramente mecânica sem qualquer interpretação hermenêutica acerca da legislação aplicável à atividade administrativa" 58 .

\subsection{Crítica e a necessidade de superação da discricionariedade no estado constitucional de direito}

Conforme assevera Abboud com muita propriedade, ocorre um embate histórico entre a discricionariedade e o direito, de maneira que ambos são excludentes entre si, ou seja, a discricionariedade é o nome jurídico

\footnotetext{
${ }^{55}$ SILVA, José Afonso da. Curso de Direito Constitucional Positivo. 22.a ed. São Paulo : Malheiros. p. 647.

${ }^{56}$ GEOGES, Abboud. Jurisdição Constitucional e direitos fundamentais. Cit p. 411.

${ }^{57}$ Ibidem.

${ }^{58}$ Idem. p. 412.
} 
para tratar de hipóteses que era excetuada a aplicação ou incidência do direito ${ }^{59}$.

Ainda na mesma trilha do autor ${ }^{60}$, nada adianta a Constituição e o processo democrático se admitirmos que as questões jurídicas possam ser julgadas por parâmetros extrajurídicos; ocorre assim uma cisão no círculo democrático.

No Estado Constitucional, os poderes estão limitados e vinculados à Constituição Federal, não apenas em sua forma e procedimentos, como também em seu conteúdo ${ }^{61}$.

Abboud $^{62}$ ainda denota que nesta luta entre o direito e a discricionariedade, sempre que a segunda vence temos a vitória do relativismo, aleatoriedade, insegurança jurídica e vontade do intérprete. Por sua vez, quando o direito prospera, temos os cientificismos, segurança e moral interpretativa pertencentes à comunidade jurídica todos fundados em uma teoria que lhe serve de base.

Um sistema jurídico, que se permite a discricionariedade como forma de resposta as questões jurídicas, em nada melhora a segurança jurídica ou mesmo a evolução do processo social jurídico, pois na discricionariedade escolhe o que se quer e não se busca aplicar a lei para obter a resposta correta.

\section{CONTROLE JURISDICIONAL DO ATO ADMINISTRATIVO}

A tese de Abboud ${ }^{63}$ é incisiva ao colocar que somente pode ocorrer a discricionariedade para solucionar questões não jurídicas, como por exemplo, a definição de um nome de uma rua ou praça.

Importante destacar que a Administração moderna tem crescido e, conseqüentemente, a tendência do controle pelo judiciário do mérito dos atos administrativos segue esta mesma trilha.

\footnotetext{
${ }^{59}$ ABBOUD, Georges. Discricionariedade: alcance da atuação administrativa e judicial no Estado Constitucional. Cit., p. 586.

${ }^{60}$ Idem. p. 587.

${ }^{61}$ Idem. p. 174.

${ }^{62}$ Idem. p. $589-590$.

${ }^{63}$ Idem. p. 272.
} 
Abboud $^{64}$ ainda denota que não pode ocorrer discricionariedade da seara jurídica, ou seja, todo o ato administrativo que soluciona questão jurídica não pode ser contaminado pela discricionariedade.

Assim, órgãos da administração que realizam atividades em esferas muito próximas da jurisdicional solucionando questões de cunho jurídico devem proporcionar uma resposta correta com base na constituição e sem a presença da discricionariedade em seu interior, como é o caso de decisões do CADE, Procons e entre outros.

Nas decisões destes órgãos, a Constituição deve ser aplicada diretamente nas decisões, pois toda solução em processo administrativo perpassa a resolução de uma questão jurídica, logo todo ato administrativo deve ser pautado em critérios jurídicos e não discricionários.

No julgamento Resp 493811-SP, o tribunal entendeu que o império da lei e seu controle estão a cargo do poder judiciário. Na esfera do Direito Administrativo, a Constituição trouxe uma nova tônica: hoje o judiciário está autorizado a examinar as razões de conveniência e oportunidade do administrador.

A relatora reconheceu existir uma nova concepção do direito administrativo após a Constituição de 1988, pela qual os administradores estão vinculados aos mandamentos constitucionais. Segundo ela, a discricionariedade não se coloca como escudo para justificar a inação ou atuação administrativa insuficiente. Desta maneira, em qualquer caso, o controle judicial do mérito do ato administrativo revela-se possível.

\subsection{Requisitos para admitir o controle de mérito do ato administrativo pelo poder judiciário}

Requisito essencial para admitir o controle do mérito do ato administrativo pelo judiciário é que ele verse sobre questão jurídica.

Observa Abboud ${ }^{65}$ que o ato administrativo pode ter seu mérito revisado pelo judiciário quando ocorrer inconstitucionalidade ou ilegalidade; é o ato que:

1.) Decide uma questão jurídica ou questão judicializável;

\footnotetext{
${ }^{64}$ Idem. p. 273.

${ }^{65}$ Idem. p. 281.
} 
2.) Soluciona, em sede administrativa, um conflito de interesses - atividade similar a jurisdicional;

3.) Em que for possível aferir sua constitucionalidade - alusão ao fato de que todo ato administrativo que decida questão jurídica pela administração deva se submeter ao Art. 37 da Constituição;

4.) Atinge direito subjetivo ou interesse jurídico. Sempre que um ato atingir direito subjetivo de alguém, nascerá uma pretensão que permitirá ajuizar ação contrária ao próprio ato, $\mathrm{e}$

5.) Pela força própria do ato torna-se obrigatória sua motivação.

\subsection{Requisitos obrigatórios que o ato administrativo deve atender}

Abboud ${ }^{66}$ realiza um profundo estudo sobre os Requisitos obrigatórios que o ato administrativo deve atender. Partindo do ponto que os atos administrativos não podem ser dicionários, ele constrói os requisitos mínimos a serem preenchidos por um ato administrativo para que não seja promovida a cassação pelo Judiciário.

O presente estudo traz um sumário destes requisitos que são: deve estar autorizado ou embasado na Constituição ou na lei; deve ser proporcional; deve estar assentado no interesse social e deve ser rigorosamente fundamentado, conforme descrito abaixo.

\subsubsection{Deve estar autorizado ou embasado na constituição ou na lei}

A lei limita as atividades da Administração Pública, subordinando-a à ordem jurídica e, portanto, à legalidade. Não existe procedimento administrativo se lhe faltar como fonte um texto de lei. Os atos administrativos sofrem limitação da Constituição, que incluir a proteção dos direitos fundamentais.

${ }^{66}$ Idem. p. 282-311. 


\subsubsection{Deve ser proporcional}

Todo ato administrativo está vinculado ao texto constitucional e logo precisa ser proporcional.

Não se trata de simples juízo de ponderação que permite a discricionariedade; trata-se de proporcionalidade para proibição da proteção deficiente e proibição do excesso.

Toda a limitação a direito fundamental deverá ser proporcional, mas especificamente, precisará observar a proibição de excesso, a fim de impedir que a restrição ao direito fundamental culmine no aniquilamento daquele direito.

\subsubsection{Deve estar assentado no interesse social}

$\mathrm{O}$ ato administrativo que atinge a esfera de acaso dos particulares deve estar constitucionalmente autorizado e assentar-se no interesse social, e não no interesse público. Não se pode fazer restrição a direito fundamental com fundamento apenas no interesse público.

\subsubsection{Deve estar rigorosamente fundamentado}

A administração formaliza seu ato pela motivação para decidir conforme quer, algo que ela faria, mesmo se não tivesse o dever de motivar. A administração nunca saberá previamente qual o destino da rota traçada, porque a administração escolhe o destino e depois formaliza uma rota (motivação), prestigiando a inautêntica prática do decido depois fundamento. 
Inicialmente, conforme observa Abboud, existe um embate histórico entre a discricionariedade e o direito, de maneira que ambos são excludentes entre si, ou seja, a discricionariedade é o nome jurídico para tratar de hipóteses que era excetuada a aplicação ou incidência do direito ${ }^{67}$.

Ainda segundo o mesmo autor ${ }^{68}$, nada adianta a Constituição e o processo democrático se admitirmos que as questões jurídicas possam ser julgadas por parâmetros extrajurídicos; ocorre assim uma cisão no círculo democrático.

Segundo Streck, há um direito fundamental a uma resposta correta, que deve ser entendida como uma resposta adequada à Constituição ${ }^{69}$. $\mathrm{O}$ mesmo autor ainda assevera que a resposta correta e adequada à Constituição é aquela antirelativista, usando a hermenêutica como uma blindagem contra interpretações arbitrárias, decisionismos e discricionarieda$\operatorname{des}^{70}$.

Assim, as decisões judiciais e administrativas que versem sobre questões de direito fundamentais passam a ter status de direito fundamental.

Para Paulo Otero, a vinculação ao texto constitucional ocorre em virtude de substituição da lei pela Constituição como fundamento direto e imediato do agir administrativo sobre determinadas matérias. Esta substituição permitiu que a constituição passasse a ser o fundamento direto do agir administrativo, tendo seu reflexo imediato em duas áreas de incidência: a) a Constituição torna-se norma direta e imediatamente habilitadora da competência administrativa; b) a Constituição passa a ser critério imediato da decisão administrativa ${ }^{71}$.

Eduardo García de Enterría e Ramón Fernandez asseveram que a vinculação da Administração Pública ao Direito faz com que não exista nenhum espaço livre para a administração agir com um poder ajuridico. Desde modo, o Direito não cria para a Administração um espaço em que dentro dela ela pode agir com total liberdade, pelo contrário, o Direito, principalmente os dispositivos constitucionais, condiciona e determina de

\footnotetext{
${ }^{67}$ Idem. p. 586.

${ }^{68}$ Idem. p. 587.

${ }^{69}$ STRECK, Lenio Luiz. O que é isto - decido conforme minha consiciência? 4.a Ed. revista, Porto Alegre : Livraria do Advogado, 2013. p. 92.

${ }^{70}$ Idem. p. 93.

${ }^{71}$ OTERO, Paulo. Legalidade e Administração pública. O sentido da vinculação administrativa à juridicidade. Coimbra : Almedina, 2003. - § 17, n. 17.1.1. p. 735.
} 
forma positiva a ação administrativa, que será inválida se estiver em desconformidade com o Direito. ${ }^{72}$

E ainda os mesmos autores destacam que:

"la interpretación conforme a la Constituición de toda y cualquier norma del ordenamiento tinene un correlación lógica en la prohibición, que hay que estimar implícita, de cualquier construcción interpretativa o dogmática que concluya en un resultado directa o indirectamente contratdictorio con los valores constitucionais". ${ }^{73}$

Desta forma, podemos entender que Direito e Discricionariedade se excluem, ou seja, onde um domina o outro é eliminado. Com isto, não é possível falar em resposta correta que tenha em seu conteúdo a discricionariedade.

Como estamos desenvolvendo no presente artigo, a resposta correta é aquela que tem bases hermenêuticas, construída com base resultado da interpretação dos dados lingüísticos e extralingüísticos, conforme teoria estruturante de Müller, com base na historicidade interpretativa que se torna elemento fundamental da compreensão de norma jurídica e adequada à Constituição, ou seja, a discricionariedade não pode ser conteúdo de tal processo de construção.

5

\section{HÁ SUPREMACIA DO INTERESSE PÚBLICO SOBRE DIREITOS FUNDAMENTAIS}

\subsection{Conceito de direito fundamental}

\footnotetext{
${ }^{72}$ GARCÍA DE ENTERRÍA, Eduardo e FERNÁNDEZ, Tomás-Ramón. Curso de Derecho Administrativo, 8.a Ed. Madrid : Civitas, 1998. p. 432.

${ }^{73}$ GARCÍA DE ENTERRÍA, Eduardo e FERNÁNDEZ, Tomás-Ramón. Curso de Derecho Administrativo, V. I, Duodécima edición - reimpressión 2005. p. 111.
} 
Para Georges Abboud, "Direitos Fundamentais constituem na atualidade o conceito que engloba os direitos humanos universais e os direitos nacionais dos cidadãos. As duas classes de direitos são, ainda que com intensidade diferente, parte integrante necessária da cultura jurídica de todo o Estado Constitucional". ${ }^{74}$

Os direitos fundamentais, na trilha do mesmo autor ${ }^{75}$, representam um entrecruzamento de interesses públicos e interesses individuais; trata-se de uma de uma junção destes dois direitos. Desta forma, ocorrendo uma lesão a um direito fundamental, o interesse público também é afetado. São por estas razões que os direitos fundamentais estão catalogados e assegurados nos textos constitucionais ${ }^{76}$.

\subsection{Direitos fundamentais e a limitação e vinculação do poder público}

O Poder Público, no Estado de Direito, sofre uma forte limitação em relação a sua atuação quando está diante de Direitos Fundamentais. Os Poderes estão, desta forma, descritos, vinculados e limitados pela Constituição.

A competência, a forma, a limitação para produção legislativa e caracterização dos poderes estão descritas na Constituição, e ela é a grande proteção aos Direitos Fundamentais ao estabelecer a toda estrutura de poderes limitações e controles.

Nas palavras de Abboud, "os direitos fundamentais asseguram ao cidadão um feixe de direitos e garantias que não poderão ser violados por nenhuma das esferas do Poder Público. Os referidos direitos apresentam dupla função: constituem prerrogativas que asseguram diversas posições jurídicas ao cidadão, ao mesmo tempo em que constituem limites/restrições à atuação do Estado" 77 .

\footnotetext{
${ }^{74}$ ABBOUD, Georges. O Mito da supremacia do interesse público sobre o privado - a dimensão constitucional dos direitos fundamentais e os requisitos necessários para se autorizar restrição a direitos fundamentais. RT 907, maio/2011. p 63.

${ }^{75}$ Idem. p 99.

${ }^{76}$ ABBOUD, Georges. Jurisdição Constitucional e direitos fundamentais. p. 341.

${ }^{77}$ ABBOUD, Georges. O Mito da supremacia do interesse público sobre o privado - a dimensão constitucional dos direitos fundamentais e os requisitos necessários para se autorizar restrição a direitos fundamentais. p. 64.
} 
Reinhold Zippelius coloca que: "a função principal dos direitos fundamentais consiste em proteger um espaço de liberdade individual contra a ingerência do poder do Estado e contra a sua expansão totalitária" 78

Neste sentido, segundo Carlos Eduardo Pereira Furlani, “é possível afirmar, resumidamente, que existem quatro funções primordiais dos direitos fundamentais, quais seriam: limitar a atuação do Estado com os particulares (função negativa); limitar a atuação entre particulares (função negativa); proporcionar bem-estar aos particulares por atos estatais que tragam efetividade aos direitos (função positiva); garantir a participação democrática (função positiva)" 79 .

Podemos entender então, que a função negativa dos direitos fundamentais é obrigar o Estado a abster-se de invadir a esfera privada das pessoas, ou seja, opera como uma proteção contra eventuais abusos do Estado.

Na mesma linha de raciocínio, Peter Häberle denota que: "no ordenamento jurídico-constitucional da Lei Fundamental, os direitos fundamentais têm um duplo significado: eles mesmos são valores supremos, e possibilitam ao homem procurar e atualizar valores, ao tempo em que garantem o status liberatis. Os direitos fundamentais são, por um lado, expressão de um ordenamento de liberdade já realizado e, simultaneamente, são pressupostos para que esse ordenamento se constitua de novo através da atualização da liberdade de todos" ${ }^{80}$.

Zippelius, ainda denota que: "as garantias dos direitos fundamentais traçam limites não só às competências estatais de regulação, mas atribuem também ao Estado a tarefa de limitar e assegurar, por lei e pela respectiva interpretação desta, os direitos dos indivíduos por forma a que sejam salvaguardados os âmbitos de liberdade, consagrados nos direitos fundamentais, e a que os bens, como a vida, saúde, a honra e a isenção de coação, se possa desenvolver na maior medida possível" 81 .

\footnotetext{
${ }^{78}$ ZIPPELIUS, Reinhold. Teoria Geral do Estado. 3.o Ed. Lisboa, PT: Fundação Calouste Gulbenkian, 1997. p. 419.

${ }^{79}$ FURLANI, Carlos Eduardo Pereira. A vinculação da supremacia do interesse público na Constituição Federal de 1988. Dissertação de mestrado. PUC SP - 2011. p. 88.

${ }^{80} \mathrm{HÄBERLE}$, Peter. La garantía del contenido esencial dos direitos fundamentais. Madri: Dykinson, 2003. p. 7.

${ }^{81}$ ZIPPELIUS, Reinhold. Teoria Geral do Estado. Tradução de Karin Praefke-Aires Coutinho - coordenação de J. J. Gomes Canotilho. 3.a ed. Fundação Calouste Gulbenkian. p 440 .
} 


\subsection{Mito da supremacia do interesse público sobre os direitos fundamentais}

Diversos administrativistas brasileiros entendem que o interesse público tem supremacia sobre o particular e estes parecem ignorar a Constituição e os direitos fundamentais ${ }^{82}$. Tal questão é uma posição equivocada e comumente difundida, e gera um grande risco para a proteção e tutela dos direitos fundamentais.

Para Abboud, "os direitos fundamentais apresentam duplo âmbito de vinculação, posto que, ao mesmo tempo em que os particulares são sujeitos ativos desses direitos, em determinados, momentos, eles poderão ser os sujeitos passivos (destinatários) diretos deles. Assim, os direitos fundamentais pertencem aos particulares permitindo sua oponibilidade contra o Poder Público, bem como contra outros particulares, estabelecendo entre eles verdadeiras relações fundamentais" ${ }^{83}$.

Vale destacar que os direitos fundamentais constituem um conquista histórica e a sua inobservância representa um retrocesso no processo civilizador da sociedade.

Dworking assevera que a primazia dos direitos fundamentais sobre o interesse público é premissa fundamental para o Estado Democrático de direito; trata-se da efetiva limitação contra o próprio governo e proteção do particular contra eventuais maiorias ${ }^{84}$.

Nesta linha, entendemos que o interesse público não garante diretamente os direitos fundamentais e também o interesse público não está inserido nos direitos fundamentais.

\footnotetext{
${ }^{82}$ AVILA. Humberto. Repensando o "Princípio da supremacia do interesse público sobre o Particular". Revista Eletrônica sobre a reforma do Estado (RERE). Salvador, Instituto Brasileiro de Direito Público. N.o 11, setembro/outubro/novembro, 2007. Disponível na Internet: 〈http://www.direitodoestado.com.br/rere.asp >. Acesso em: 02 de setembro de 2013.

${ }^{83}$ ABBOUD, Georges. O Mito da supremacia do interesse público sobre o privado - a dimensão constitucional dos direitos fundamentais e os requisitos necessários para se autorizar restrição a direitos fundamentais. $\mathrm{p} 96$.

${ }^{84}$ DWORKING, Ronald. Levando os Direitos a sério. 3.a Ed. São Paulo : Martins Fontes, 2010. p. 294.
} 
Os Diretos fundamentais, como observa Dworking ${ }^{85}$, são direitos oponíveis contra o Poder Público e a própria existência deles seria colocada em risco se fosse permitida alguma restrição contra eles.

Além disso, os Direitos Fundamentais são contramajoritários, como observa Abboud ${ }^{86}$, ou seja, servem de resguardo contra o Poder Público e proteção do cidadão contra eventuais maiorias que buscam restringi-los.

Abboud ainda denota que: "a lesão aos direitos fundamentais acarreta lesão ao próprio interesse público, afinal a defesa dos direitos fundamentais interessa tanto ao cidadão como à própria comunidade; uma possível restrição a um direito fundamental pode ocorrer diante da ponderação do caso concreto desde que previsto na própria Constituição Federal ou autorizado por ela, ou ainda que não autorizado no texto constitucional a restrição tiver como objetivo salvaguardar outros direitos fundamentais" 87.

Na mesma linha, Eduardo García de Enterría e Tomás-Ramon Fernández, observam que:

"Es absolutamente inadmisible afirmar, como resulta de ciertar exposiciones y aún de algunas decisiones jurisprudenciales, que la Administración disponga de un poder general implícito o derivado de la cláusula general del orden público (...) para poder condicionar, limitar o intervenir los derechos y libertades constitucionalmente proclamados en orden a una hipotética articulación de los mismos con la utilidade común o general. Estas es una tesis rigorosamente procedente del absolutismo (...) pero totalmente incompatible con las construcción moderna del Estado de Derecho". 88

\footnotetext{
${ }^{85}$ Idem. p. 296-298.

${ }^{86}$ ABBOUD, Georges. O Mito da supremacia do interesse público sobre o privado - a dimensão constitucional dos direitos fundamentais e os requisitos necessários para se autorizar restrição a direitos fundamentais. p 101.

${ }^{87}$ Idem. p 103.

${ }^{88}$ ENTERRÍA, Eduardo García de; FERNÁNDEZ, Tomáz-Rámon. Curso de Derecho Administrativo. 7.a Ed., Madrid: Civitas, 2000, p. 63-64.
} 


\subsection{Restrição a direitos fundamentais}

Como observa Abboud89, Constituição Suíça define os seguintes requisitos para restrição ao direito fundamental:

a.) Restrição deve estar fundada em uma base legal;

b.) Restrição deve ser feita em prol do interesse público ou então com o intuito de proteger outros direitos fundamentais;

c.) Limitação deve ser proporcional;

d.) Direito fundamental não pode ser totalmente aniquilado em sua essência.

Desta forma, podemos entender, com base na Constituição Suíça, que os Direitos Fundamentais não podem ser simplesmente limitados por decisão política.

Toda a construção histórica destes Direitos mostra que eles são fruto de um processo de evolução social e civilizador; qualquer limitação a eles representam um retrocesso e um grande risco para a sociedade.

\section{DE QUE FORMA SE PÕE O PARADIGMA - ADMINISTRAÇÃO E JURISDICIONADO - NO ESTADO CONSTITUCIONAL}

Pedro Machete foi o autor que concebeu o conceito de administração pública paritária (par a par com o cidadão) e ela decorre da nova posição constitucional da Administração Pública, que, por sua vez, é conformada e informada por dois aspectos: 1) a intensificação da subordinação da Administração como exigência de fundamento legal específico para cada uma das suas decisões e 2). Integração dos cidadãos particulares na Constituição e no ordenamento do Estado via do reconhecimento de direitos fundamentais aplicáveis ${ }^{90}$.

\footnotetext{
${ }^{89}$ ABBOUD, Georges. O Mito da supremacia do interesse público sobre o privado - a dimensão constitucional dos direitos fundamentais e os requisitos necessários para se autorizar restrição a direitos fundamentais. p 103.

${ }^{90}$ MACHETE, Pedro. A subordinação da Administração Pública ao Direito e a dogmática do direito administrativo no âmbito do Estado de Direito Democrático, in: Augusto de Athayde; João Caupers; Maria da Glória Garcia (org.) Em homenagem ao Professor Doutor Diogo de Freitas do Amaral. Coimbra: Almedina, 2010. p. 219-220.
} 
Segundo a doutrina de Machete, Estado e Indivíduo apresentamse um perante o outro como titulares de direito e deveres recíprocos, e por esta razão, temos uma administração par a par com o cidadão.

Ainda segundo o mesmo autor, no Estado Constitucional não há ação do Poder Público que não precise estar embasada em razões jurídicas. Não há ato do poder público, que decida questões jurídicas, que não possa ser corrigido e controlado ${ }^{91}$. Não há espaço para um agir soberano que não preste contas ou que não seja imune à judicial review.

Por sua vez, Abboud observa que somente a Constituição é Soberana, não existe nenhum poder (executivo, legislativo e judiciário) soberano; todos eles agem somente com amparo constitucional ${ }^{92}$.

Devem-se revisar os conceitos de Direito Administrativo em que o cidadão deixa assim de ser mero súdito e que o ato administrativo possa ser pautado por critério volitivo do administrador, conforme destaca Abboud $^{93}$.

A posição jurídica dos particulares perante os poderes públicos, em uma administração paritária, é indispensável ao reconhecimento daqueles como sujeitos jurídicos e à conseqüente autonomia destes perante os mencionados poderes. Os particulares são pessoas dotadas de liberdade quanto à determinação dos fins que perseguem e na forma que orientam as suas vidas. Assim, eles têm meios jurídicos necessários, por iniciativa própria e com autonomia, de defenderem-se das agressões ilegais e exigirem a satisfação dos seus interesses nos termos legalmente previstos ${ }^{94}$.

Administração, então, não pode ignorar os comandos constitucionais e principalmente os direitos fundamentais e agir livremente. Insta destacar ainda que a Administração passe a ter sua atuação limitada pela Constituição e pelos Direitos Fundamentais, e ao estar limitada e reconhecer os direitos fundamentais passa a ter uma posição de igualdade com os cidadãos.

\footnotetext{
${ }^{91}$ Idem. p. 220.

${ }^{92}$ ABBOUD, Georges. Discricionariedade: alcance da atuação administrativa e judicial no Estado Constitucional. p. 177.

${ }^{93}$ Idem. p. 282-311.

94 Ibidem.
} 


\section{CONCLUSÃO}

1. O conceito de discricionariedade teve uma maior análise ao longo da história na esfera administrativa do que na judicial, pois ela é tratada como um conceito pertencente à doutrina administrativa.

2. Ocorre um embate histórico entre a discricionariedade e direito: a discricionariedade é um não-dominio do direito. Sempre que a discricionariedade prospera temos a vitória do relativismo, aleatoriedade, insegurança jurídica e vontade do intérprete. Por sua vez, quando o direito vence, temos o cientificismo, segurança e moral interpretativa pertencentes à comunidade jurídica todos fundados em uma teoria que lhe serve de base.

3. No Estado Constitucional, os poderes estão limitados e vinculados à Constituição Federal, não apenas em sua forma e procedimentos, como também em seu conteúdo. Assim, nada adianta a Constituição e os processos democráticos se admitirmos que as questões jurídicas possam ser julgadas por parâmetros extrajurídicos, como é o caso da discricionariedade.

4. A única forma de admissão da discricionariedade em atos administrativos é quando tratar de questões não jurídicas, como por exemplo, a definição do nome de uma rua.

5. No estado democrático de direito, o controle do mérito do ato administrativo pelo judiciário deve ocorrer sempre que o ato versar sobre questão jurídica.

6. Para ocorrência de resposta correta em atos administrativos, estes devem se fundar na constituição e não podem ser eivados de conteúdo ou decisões discricionárias, pois Direito e Discricionariedade se excluem.

7. Direitos Fundamentais englobam os direitos humanos universais e os direitos nacionais dos cidadãos e são assegurados na Constituição. Ainda observe que os direitos fundamentais representam um entrecruzamento de interesses públicos e interesses individuais e ocorrendo uma lesão a um direito fundamental, o interesse público também é afetado.

8. Os direitos fundamentais constituem um conquista histórica e a sua inobservância representa um retrocesso no processo civilizador da sociedade

9. A questão da supremacia do interesse público sobre o particular é uma posição equivocada e comumente difundida. Tal posição gera 
um grande risco para a proteção e tutela dos direitos fundamentais. Os direitos fundamentais pertencem aos particulares permitindo sua oponibilidade contra o Poder Público, bem como contra outros particulares.

10. Administração Pública Paritária (par a par com o cidadão) decorre da nova posição constitucional da Administração Pública, pois esta passa a ter maior subordinação à lei e à Constituição e pela integração dos cidadãos particulares na Constituição e no ordenamento do Estado via do reconhecimento de direitos fundamentais oponíveis à Administração.

11. A Administração passa a ter sua atuação limitada pela Constituição e pelos Direitos Fundamentais e, ao estar limitada e reconhecer os direitos fundamentais, passa a ter uma posição de igualdade com os cidadãos.

\section{REFERÊNCIAS BIBLIOGRÁFICAS}

ABBOUD, Georges. Discricionariedade: alcance da atuação administrativa e judicial no Estado Constitucional. Tese de Doutorado em Direito. Pontifícia Universidade Católica de São Paulo, 2013. . Jurisdição Constitucional e direitos fundamentais. São Paulo : Editora Revista dos Tribunais, 2011.

. O Mito da supremacia do interesse público sobre o privado - a dimensão constitucional dos direitos fundamentais e os requisitos necessários para se autorizar restrição a direitos fundamentais. RT 907, maio/2011

AFONSO DA SILVA, José. Curso de Direito Constitucional Positivo. 22.a ed. São Paulo : Malheiros.

AUSTIN, John L. How to do things with words. 2. Ed, Cambridge: Harvard University Press, 1975.

AVILA. Humberto. Repensando o "Princípio da supremacia do interesse público sobre o Particular". Revista Eletrônica sobre a reforma do Estado (RERE). Salvador, Instituto Brasileiro de Direito Público. N.o 11, setembro/outubro/novembro, 2007. Disponível na Internet: <http://www.direitodoestado.com.br/rere.asp>. Acesso em: $02 \mathrm{de}$ setembro de 2013.

BANDEIRA DE MELO, Celso Antonio. Discricionariedade e controle jurisdicional. 2.a Ed. 11.a tir. São Paulo: Malheiros Editores, 2012. 
BLACK'S LAW DICTIONARY - Third Pocket Edition - Thomson West $-2006$.

CASTANHEIRA NEVES, Antonio. O problema da discricionariedade. In: Digesta: escritos acerca do Direito, do pensamento jurídico, de sua metodologia. Coimbra Editora, 1996, v.1, p. 532-534.

COMANDIRA, Julio Rodolfo; ESCOLA, Héctor Jorge e COMANDIRA, Julio Pablo. Custo de Derecho administrativo. Buenos Aires: Abeledo-Perrot.

DWORKING, Ronald. Levando os Direitos a sério. 3.a Ed. São Paulo : Martins Fontes, 2010

FARIA, Edimur Ferreira. Controle do mérito do ato administrativo pelo judiciário. Belo Horizonte : Editora Fórum, 2011

FERNÁNDEZ, Tomás Ramón. Discrecionalidad, Arbitrariedad y Control Jurisdiccional. Lima: Palestra Editores, 2006.

FURLANI, Carlos Eduardo Pereira. A vinculação da supremacia do interesse público na Constituição Federal de 1988. Dissertação de mestrado. PUC SP - 2011.

GARCÍA DE ENTERRÍA, Eduardo de; FERNÁNDEZ, Tomáz-Rámon. Curso de Derecho Administrativo. 7.a Ed., Madrid: Civitas, 2000 , Eduardo e , Tomás-Ramón. Curso de Derecho Administrativo, 8.a Ed. Madrid : Civitas, 1998. , Eduardo e , Tomás-Ramón, Tomás-Ramón. Curso de Derecho Administrativo, V. I, Duodécima edición reimpressión 2005.

, Eduardo e , Tomás-Ramón, Tomás-Ramón. Curso de Derecho Administrativo, V. II, Duodécima edición reimpressión 2005.

HÄBERLE, Peter. La garantía del contenido esencial dos direitos fundamentais. Madri: Dykinson, 2003.

JUSTEN FILHO, Marçal. Comentários à lei de licitações e contratos administrativos. 14.a Ed. - São Paulo: Dialética, 2010.

KEYES. W. Noel. Government contracts in a nutshell. Fourth Edition Pepperdine University School of Law - Thomas West.

KRELL, Andreas J. Discricionariedade Administrativa e conceitos legais indeterminados: limites do controle judicial no âmbioi dos interesses difusos. 2. ed. rev., atual. e ampl. - Porto Alegre : Livraria do Advogado Editora, 2013.

MACHETE, Pedro. A subordinação da Administração Pública ao Direito e a dogmática do direito administrativo no âmbito do Estado de 
Direito Democrático, in: Augusto de Athayde; João Caupers; Maria da Glória Garcia (org.) Em homenagem ao Professor Doutor Diogo de Freitas do Amaral. Coimbra: Almedina, 2010.

MARIENHOFF, Miguel S. Tratado de Derecho Administrativo, t. II, 5. ${ }^{\text {a }}$ ed., Buenos Aires: Abeledo Perrot, 2011.

MARTINS, Ricardo Marcondes. Efeitos dos vícios do ato administrativo. São Paulo : Malheiros, 2008.

MEIRELLES, Hely Lopes. Direito Administrativo Brasileiro. 29a ed. Atualizado por Eurico de Andrade Azevedo et alii. São Paulo: Editora Malheiros, 2004

OTERO, Paulo. Legalidade e Administração pública. O sentido da vinculação administrativa à juridicidade. Coimbra: Almedina, 2003. PIETRO, Maria Sylvia Zanella di. Direito Administrativo. 24.a Ed - São Paulo : Atlas, 2011.

Discricionariedade Técnica e Discricionariedade Administrativa. Revista Eletrônica de Direito Administrativo Econômico (REDAE), Salvador, Instituto Brasileiro de Direito Público, n.o 09, fevereiro/março/abril, 2007. Disponível na internet: http://www.direitodoestado.com.br/redae.asp acesso em 28 de setembro de 2013SEABRA FAGUNDES, Miguel. O controle dos atos administrativos pelo Poder Judiciário. 8.a ed. autal. por Gustavo Binenbojm. Rio de Janeiro : Foresen, 2010, p. 91-92.

SOUSA, Antônio Francisco de. Conceitos Indeterminados. Coimbra : Livraria Almedina, 1994

STRECK, Lenio Luiz. O que é isto - decido conforme minha consiciência? 4.a Ed. revista, Porto Alegre : Livraria do Advogado, 2013.

Verdade e Consenso. Constituição, Hermenêutica e Teorias Discursivas da Possibilidade à necessidade de respostas corretas em Direito. 4.a Ed. revista, Porto Alegre : Livraria do Advogado, 2013. ZIPPELIUS, Reinhold. Teoria Geral do Estado. 3.o Ed. Lisboa, PT: Fundação Calouste Gulbenkian, 1997.

Teoria Geral do Estado. Tradução de Karin Praefke-Aires Coutinho - coordenação de J. J. Gomes Canotilho. 3.a ed. Fundação Calouste Gulbenkian 